\title{
Effects of increasing dietary concentrations of fish oil on lamb performance, ruminal fermentation, and leptin gene expression in perirenal fat
}

\author{
Pedro Abel Hernández-García ${ }^{1}$, Germán David Mendoza-Martínez ${ }^{2^{*}}$, Nallely Sánchez ${ }^{2}$, José \\ Antonio Martínez-García ${ }^{2}$, Fernando Xicotencatl Plata-Pérez ${ }^{2}$, Alejandro Lara-Bueno ${ }^{3}$, Silene \\ Mariella Ferraro ${ }^{2}$
}

\footnotetext{
${ }^{1}$ Universidad Autónoma del Estado de México, Amecameca, Estado de México, México.

${ }^{2}$ Universidad Autónoma Metropolitana, Xochimilco, Departamento de Producción Agrícola y Animal, Mexico City, México.

${ }^{3}$ Universidad Autónoma Chapingo, Texcoco, Estado de México, México.
}

\begin{abstract}
The objective of this study was to evaluate the effects of four levels of fish oil on lamb performance, carcass yield, ruminal fermentation, and leptin gene expression in perirenal fat. Thirty-two lambs $(24.10 \pm 2.15 \mathrm{~kg}, \mathrm{Katahdin} \times$ Pelibuey) were used in a completely randomized experimental design. The lambs were assigned to one of four dietary treatments ( $\mathrm{n}=8 \mathrm{lambs} /$ treatment), expressed as $\mathrm{g} / \mathrm{kg}$ DM basis: 0 fish oil and 300 corn; 10 fish oil and $250 \mathrm{corn} ; 20$ fish oil and 205 corn; and 30 fish oil and 170 corn. The lambs were weighed on consecutive days at the beginning (days 0 and 1 ) and at the end (days 55 and 56) of the trial. Ruminal fluid samples were collected on day 56 to evaluate the ruminal fermentation pattern. The lambs were slaughtered on day 56; perirenal adipose tissue samples were collected and the carcass yields were recorded. Volatile fatty acids, ammonia N, and leptin mRNA expression were not affected by the dietary treatments. However, the dry matter intake, average daily gain, final body weight, and the hot carcass yield showed either increased linear or quadratic responses as the proportion of fish oil increased in the ration; the estimated optimal level obtained of fish oil levels for average daily gain was $11.2 \pm 0.21 \mathrm{~g} / \mathrm{kg}$ and $12.8 \pm 4.67 \mathrm{~g} / \mathrm{kg}$ for feed conversion. Additionally, feed efficiency and backfat thickness had an increment, showing quadratic response as the proportion of fish oil increased in the diet. Increasing the fish oil concentration in the diet does not affect leptin messenger ribonucleic acid expression. The lamb performance can be improved with $12 \mathrm{~g} / \mathrm{kg}$ fish oil in diets of finishing lambs.
\end{abstract}

Key Words: finshing lambs, oils, carcasss quality

\section{Introduction}

Fish oil has been incorporated into lamb diets at concentrations of $20-30 \mathrm{~g} / \mathrm{kg}$, based on forage or concentrate, with no effect on intake or daily gain (Marinova et al., 2007; Toral et al., 2009; Annett et al., 2011). Other studies have partially replaced vegetable oils with fish oil and attempted to avoid the negative effects of the omega- 3 polyunsaturated fatty acids, which are present at high concentrations in fish oil, on lamb performance. Ferreira et al. (2014) evaluated fish oil concentrations from 2.5 to $7.5 \mathrm{~g} / \mathrm{kg}$ in lamb finishing

Received: October 31, 2016

Accepted: November 18, 2016

*Corresponding author: gmendoza@correo.xoc.uam.mx

http://dx.doi.org/10.1590/S1806-92902017000600007

How to cite: Hernández-García, P. A.; Mendoza-Martínez, G. D.; Sánchez, N.; Martínez-García, J. A.; Plata-Pérez, F. X.; Lara-Bueno, A. and Ferraro, S. M. 2017. Effects of increasing dietary concentrations of fish oil on lamb performance, ruminal fermentation, and leptin gene expression in perirenal fat. Revista Brasileira de Zootecnia 46(6):521-526.

Copyright (C) 2017 Sociedade Brasileira de Zootecnia. This is an Open Access article distributed under the terms of the Creative Commons Attribution License (http://creativecommons.org/licenses/by/4.0/), which permits unrestricted use, distribution, and reproduction in any medium, provided the original work is properly cited. diets with $40 \mathrm{~g} / \mathrm{kg}$ total oil and found no effect on intake, daily gain, or feed efficiency.

Nutrigenomics (the study of the bidirectional interactions between genes and diet) is a rapidly developing field that is changing research on nutrition (Zeisel and da Costa, 2009).

Leptin is a hormone primarily secreted by white adipocytes (Chilliard et al., 2005) and is a protein involved in the central and/or peripheral regulation of body homeostasis, energy intake, storage and expenditure, fertility, and immune functions (Ingvartsen and Boisclair 2001; Tokuda et al., 2000). The role of leptin is well documented in rodents and humans, increasing lipolysis and decreasing lipogenesis in the adipose tissues or in the liver (Havel et al., 2004; Sadri et al., 2011), but it is more poorly understood in ruminants (Chilliard et al., 2005). Chilliard et al. (2005) suggested that fatty acids, particularly linoleic, could stimulate leptin expression in ruminants as well as in rodents. However, in ruminants, the effects of fat ingestion on leptin blood concentrations have not been consistently demonstrated and the effects would likely depend on the amount of fat consumed or on other dietary interactions. Lambs supplemented with a high amount of rumen- 
protected fat increased leptin blood concentrations (Yildiz et al., 2003). Chilliard et al. (2001) found that leptin plasma concentrations were lower in a group fed a diet with moderate energy content compared with a group fed a high-energy diet. Similarly, leptin messenger ribonucleic acid (mRNA) expression increased in lactating goats fed sunflower seed oil and natural grassland hay, but not when fed an oil and corn silage diet (Bonnet et al., 2009).

It is important to identify the optimal concentration of fish oil in diet dry matter (DM), below the $30 \mathrm{~g} / \mathrm{kg}$ limit that allows for improved gain and feed conversion. We hypothesized that performance variables would show a quadratic response to fish oil in the diet of lambs, associated with changes in leptin expression. Therefore, the objective of the current study was to evaluate lamb performance, ruminal fermentation characteristics, and the expression of the leptin gene in lambs fed a high-concentrate diet supplemented with varying concentrations of fish oil.

\section{Material and Methods}

All procedures were approved by the local Animal Care and Use Committee. The experiment was conducted in Huitzilac, Morelos, Mexico.

Thirty-two male lambs $(24.10 \pm 2.15 \mathrm{~kg}$, Katahdin $\times$ Pelibuey), housed in individual pens $(0.80 \times 1.75 \mathrm{~m})$, were used in a completely randomized experimental design, where response variables were measured once; therefore, animal nested within treatment was the experimental unit. The lambs were dewormed with closantel sodium $(5 \mathrm{mg} / \mathrm{kg}$ body weight); vaccinated for Clostridium perfringens types $\mathrm{C}$ and D, Clostridium novy, C. sordeli, C. chauvoei, and C. septicum (Ultrabac 7), and dosed with vitamins A, D, and E (Vigantol $2 \mathrm{mg} / \mathrm{lamb}$ ). The lambs were assigned to one of four dietary treatments ( $\mathrm{n}=8 \mathrm{lambs} /$ treatment), expressed as $\mathrm{g} / \mathrm{kg}$ DM basis: 0 fish oil and 300 corn; 10 fish oil and 250 corn; 20 fish oil and 205 corn; and 30 fish oil and 170 corn (Table 1). The diets were balanced to be isocaloric and equal to or greater than the protein and metabolizable energy requirements of a $30 \mathrm{~kg}$ lamb gaining $200 \mathrm{~g} / \mathrm{d}$ (NRC, 2007) and maintaining a Ca:P ratio of $2: 1$.

The rations were ground (using a $1.25-\mathrm{cm}$ screen) and mixed in a grinder-mixer (Vigusa, Mexico) and provided ad libitum in individual feeders (50-cm bunk space/lamb). In the first five days of the adaptation period, lambs were fed corn stover and alfalfa (50:5) and water ad libitum. From the sixth day, the lambs were gradually adapted to the experimental diet, replacing $200 \mathrm{~g} / \mathrm{kg}$ of forages by the experimental diet every three days. Lambs had continuous access to water and were weighed on two consecutive days at the beginning (day 0 and day 1) and at the end of the trial (day 55 and day 56). Feed was provided at 08.00 and $15.00 \mathrm{~h}$. All the lambs had free access to feed, ensuring $100 \mathrm{~g}$ refusal per $\mathrm{kg}$ from the daily quantity offered, and daily intake was calculated by weighing refusals daily.

Samples of the feed and the refusals were collected daily and composited every 14 days. The dry matter and total nitrogen content of the diets were analysed according to the AOAC (2000). The cell wall analyses were conducted according to the method of Van Soest et al. (1991). Rumen fluid $(50 \mathrm{~mL})$ was extracted on day 56 at $07.00 \mathrm{~h}$ by esophageal tube obtained before morning feeding with a flexible Tygon tube. Rumen fluid was obtained using an electric vacuum pump and before being strained through a cheesecloth layer, acidified with $1 \mathrm{~mL}$ of sulphuric acid $(300 \mathrm{~g} / \mathrm{L})$, and stored in a freezer $\left(-20^{\circ} \mathrm{C}\right)$ for further analyses. The volatile fatty acids were measured using gas chromatography of samples prepared with metaphosphoric acid (Erwin et al., 1961) and the ammonia $\mathrm{N}$ was colorimetrically analysed (McCullough, 1967).

The performance variables were daily feed intake, average daily gain, feed efficiency (ratio of $\mathrm{kg}$ gained per $\mathrm{kg}$ feed intake), hot carcass yield, and ultrasound back fat of the Longissimus dorsi muscle area. The hot carcass yield was obtained following slaughter of the lambs on day 56 and the ultrasound back fat was assessed one day before slaughter (Silva et al., 2005).

Table 1 - Ingredients and nutritional composition of diets (dry matter basis) offered to finishing lambs



R. Bras. Zootec., 46(6):521-526, 2017 
Samples from the perirenal adipose deposits were removed via biopsy techniques within $4 \mathrm{~min}$ after slaughter to determine expression of leptin mRNA (Kumar et al., 1998) and total RNA was isolated from the fat by homogenization of tissue (Tissue-Tearor ${ }^{\mathrm{TM}}$, Daigger ${ }^{\circledR}$, Daigger \& Company Inc.) in Tri Reagent $\mathrm{R}$ (Sigma Chemical Co. Ltd.). Total RNA was used for reverse transcription and Leptin mRNA expression was quantified with realtime polymerase chain reaction (PCR) using the forward and reverse primers, 5'-ACAACACACGATGGAAGCAT-3' and 5'- ACCCCAAAAAGCCTGGAAAA-3, and total number of cDNA copies was estimated as described by Tricarico et al. (2002).

Data were tested for the Shapiro-Wilk test of normality and results were analysed according to a completely randomized design and were tested for linear and quadratic effects of fish oil concentration (Steel et al., 1997) and gene expression results were log-transformed prior to analysis. Data were analysed with the following model:

$$
\mathrm{Y}_{i j}=\mu+\tau_{i}+\mathrm{a}_{j(i)}+\mathrm{e}_{i j}
$$

in which $\mu$ is the mean value, $\tau_{i}$ is the treatment effect (fixed), $a_{j(i)}$ is the effect of animal nested within each treatment, and eij is the error term. If quadratic effect was significant, the optimal concentration for lamb performance variables were estimated using the derived quadratic equation $\left(-b_{1} / 2 b_{11}\right)$ from the equation $Y=b_{0}+b_{1} X+b_{11} x^{2}$ (Draper and Smith, 1998), in which $\mathrm{Y}$ is the response variable and $\mathrm{X}$ is the fish oil concentration. The response variables were also tested for simple correlations. Data were analysed with the JMP7 software (Sall et al., 2012).

In each experimental treatment, costs per $\mathrm{kg}$ of live weight and the partial net income were estimated per lamb, considering incomes (sales value) and expenditures (value of direct costs such as cost of animal, feed, veterinary costs, etc.), as described by Mendoza et al. (2015).

\section{Results}

As expected, the variables related to growth and fattening showed a quadratic response that was used to estimate the highest final body weight $(39.81 \mathrm{~kg})$, which occurred with $11.6 \mathrm{~g} / \mathrm{kg}$ fish oil, and the highest carcass weight $(19.78 \mathrm{~kg})$, which occurred with $10.3 \mathrm{~g} / \mathrm{kg}$ fish oil. The maximum average daily gain $(275 \mathrm{~g} / \mathrm{d})$ was estimated to occur with $11.2 \pm 0.21 \mathrm{~g} / \mathrm{kg}$ fish oil and the best feed conversion ratio (4.10) with $12.8 \pm 4.67 \mathrm{~g} / \mathrm{kg}$ (the best feed efficiency estimated with $13.1 \pm 0.15 \mathrm{~g} / \mathrm{kg}$ fish oil). Final body weight was positively correlated with average dry matter intake $(\mathrm{r}=0.74, \mathrm{P}<0.0001)$, average daily gain $(r=0.84, P<0.0001)$, and feed efficiency $(r=0.66$, $\mathrm{P}<0.0001)$. Although there were changes in back fat and gain-to-feed ratio, leptin gene expression was not affected by the treatments (Table 2) and leptin mRNA was not correlated with other variables.

The molar proportions of acetate and butyrate decreased linearly as fish oil concentration increased, whereas propionate increased. The total volatile fatty acid concentrations also tended to decrease in a linear manner (Table 3). There were no differences $(\mathrm{P}>0.10)$ in the ammonia $\mathrm{N}$ concentration among the treatments (Table 3 ).

Economic evaluation showed that inclusions up to $20 \mathrm{~g} / \mathrm{kg}$ of fish oil concentration were profitable, but higher amounts caused economic losses (Table 4).

\section{Discussion}

Consistent with the results of Ferreira et al. (2014), this experiment demonstrated a positive response in average daily gain with the lowest concentration of fish oil in finishing lamb rations. Overall, in studies in which fish oil concentrations were approximately $10 \mathrm{~g} / \mathrm{kg}$, final weight,

Table 2 - Effect of fish oil dietary concentration on performance of lambs fed a high-grain diet

\begin{tabular}{|c|c|c|c|c|c|c|c|c|}
\hline \multirow{2}{*}{ Item } & \multicolumn{4}{|c|}{ Fish oil concentration $(\mathrm{g} / \mathrm{kg})^{1}$} & \multirow{2}{*}{$\mathrm{SEM}^{2}$} & \multirow{2}{*}{ P-value ${ }^{3}$} & \multicolumn{2}{|c|}{ Contrast $^{4}$} \\
\hline & 0 & 10 & 20 & 30 & & & Linear & Quadratic \\
\hline Initial weight (kg) & 23.88 & 24.31 & 24.33 & 23.80 & 0.79 & 0.94 & 0.94 & 0.54 \\
\hline Final weight (kg) & 37.17 & 39.50 & 38.68 & 33.03 & 1.14 & 0.002 & 0.05 & 0.001 \\
\hline Dry matter intake (DMI) $(\mathrm{g} / \mathrm{d})$ & 1122 & 1146 & 1080 & 898 & 35.45 & 0.0001 & 0.0001 & 0.008 \\
\hline Average daily gain (g) & 237 & 271 & 256 & 165 & 16.28 & 0.0004 & 0.003 & 0.0006 \\
\hline G:F (kg of gain/kg of DMI) & 0.176 & 0.201 & 0.194 & 0.156 & 0.006 & 0.07 & 0.21 & 0.005 \\
\hline Hot carcass weight $(\mathrm{kg})$ & 18.66 & 19.51 & 18.83 & 16.02 & 0.79 & 0.002 & 0.02 & 0.02 \\
\hline Hot carcass yield $(\%)$ & 54.49 & 54.08 & 51.77 & 52.22 & 1.45 & 0.47 & 0.17 & 0.76 \\
\hline Back fat (mm) & 1.87 & 2.50 & 2.87 & 2.00 & 0.18 & 0.002 & 0.37 & 0.0004 \\
\hline Leptin $^{5}$ & 8.83 & 8.59 & 8.87 & 9.03 & 0.179 & 0.45 & 0.31 & 0.32 \\
\hline
\end{tabular}

${ }^{1}$ Dry matter basis.

${ }^{2}$ Standard error of the mean; $\mathrm{n}=8$

${ }^{3} \mathrm{P}$-value for the F-Test of the mean for the dietary treatment.

${ }^{4} \mathrm{P}$-value for linear and quadratic functions in response to increasing fish oil.

${ }^{5}$ Log. No. copies of leptin mRNA expressed. 
Table 3 - Effect of fish oil dietary concentration on ruminal fermentation pattern and ammonia $\mathrm{N}$

\begin{tabular}{|c|c|c|c|c|c|c|c|c|}
\hline \multirow{2}{*}{ Item } & \multicolumn{4}{|c|}{ Fish oil concentration $(\mathrm{g} / \mathrm{kg})^{1}$} & \multirow{2}{*}{$\mathrm{SEM}^{2}$} & \multirow{2}{*}{ P-value ${ }^{3}$} & \multicolumn{2}{|c|}{ Contrast $^{4}$} \\
\hline & 0 & 10 & 20 & 30 & & & Linear & Quadratic \\
\hline Acetate $(\%)$ & 66.75 & 64.01 & 61.72 & 59.39 & 1.22 & 0.001 & 0.0001 & 0.87 \\
\hline Propionate $(\%)$ & 20.07 & 24.71 & 28.04 & 30.72 & 1.35 & 0.0001 & 0.0001 & 0.47 \\
\hline Butyrate (\%) & 13.16 & 11.26 & 10.23 & 9.88 & 0.76 & 0.02 & 0.003 & 0.31 \\
\hline Total volatile fatty acids $(\mathrm{mMol} / \mathrm{L})$ & 48.09 & 49.85 & 39.68 & 33.45 & 6.32 & 0.24 & 0.06 & 0.53 \\
\hline $\mathrm{N}-\mathrm{NH}_{3}(\mathrm{mg} / \mathrm{dL})$ & 13.91 & 12.00 & 12.55 & 12.98 & 1.04 & 0.62 & 0.63 & 0.27 \\
\hline
\end{tabular}

${ }^{1}$ Dry matter basis.

${ }^{2}$ Standard error of the mean; $\mathrm{n}=8$.

${ }^{3} \mathrm{P}$-value for the $\mathrm{F}$ test of the mean for the dietary treatment.

${ }^{4} \mathrm{P}$-value for linear and quadratic functions in response to increasing fish oil.

Table 4 - Economic analysis of the inclusion of fish oil concentration in diets of finishing lambs

\begin{tabular}{lcccc}
\hline \multirow{2}{*}{ Item } & \multicolumn{4}{c}{ Fish oil concentration $(\mathrm{g} / \mathrm{kg})^{1}$} \\
\cline { 2 - 5 } & 0 & 10 & 20 & 30 \\
\hline Duration of fattening days & 56 & 56 & 56 & 56 \\
Total weight gain (kg) & 13.27 & 15.17 & 14.33 & 9.24 \\
Cost per kg feed (US\$) & 0.50 & 0.513 & 0.514 & 0.524 \\
Total feed intake (as feed) (kg) & 73.92 & 75.60 & 70.00 & 59.36 \\
Feed costs (US\$) & 36.96 & 38.80 & 35.99 & 31.11 \\
Weight sold (depleted) (kg) & 36.42 & 38.71 & 37.26 & 32.40 \\
Initial cost of animal (US\$) & 63.68 & 64.82 & 64.93 & 61.78 \\
Other costs per animal (US\$) & 3.00 & 3.00 & 3.00 & 3.00 \\
Selling price (US\$/kg) & 2.91 & 2.91 & 2.91 & 2.91 \\
Total sales revenues (US\$) & 106.24 & 112.90 & 108.70 & 94.52 \\
Partial net income per animal (US\$) & +2.34 & +6.02 & +4.50 & -1.60 \\
\hline
\end{tabular}

${ }^{1}$ Dry matter basis.

average daily gain, and feed efficiency were unaffected (Toral et al., 2009; Annett et al., 2011; Ferreira et al., 2014), but when the fish oil concentrations were above $30 \mathrm{~g} / \mathrm{kg}$, the intake and average daily gain were reduced (Kitessa et al., 2001; Wachira et al., 2002; Marinova et al., 2007). Annett et al. (2011) observed that with $35 \mathrm{~g} / \mathrm{kg}$ fish oil, the subcutaneous fat depth over the leg area in lambs increased slightly and Marinova et al. (2007) reported that a diet with $10 \mathrm{~g} / \mathrm{kg}$ fish oil mixed with $20 \mathrm{~g} / \mathrm{kg}$ sunflower oil reduced the subcutaneous fat in the loin, but intramuscular fat was higher in the shoulder.

Results from other experiments have indicated that changes in the ruminal fermentation pattern are related to the amount of fish oil; reductions in acetate and increases in propionate were reported at concentration of $40 \mathrm{~g} / \mathrm{kg}$ fish oil (Wachira et al., 2002; Fievez et al., 2003); and acetate was only reduced at concentrations between 2.5 and $10 \mathrm{~g} / \mathrm{kg}$ (Toral et al., 2009; Ferreira et al., 2014). However, the forage proportion can modify the response. Chikunya et al. (2004) used $50 \mathrm{~g} / \mathrm{kg}$ fish oil in a forage-based diet and did not detect changes in molar proportions of volatile fatty acids. Results of the response of butyrate to fish oil have been inconsistent and the only change was observed in an experiment with
$10 \mathrm{~g} / \mathrm{kg}$ fish oil (Toral et al., 2009). Marinova et al. (2007) suggested that changes in propionate and acetate are related to the depression of acetate-producing bacteria, which are inhibited by polyunsaturated fatty acids. However, in high-grain diets, these bacteria do not grow (Russell et al., 2009); therefore, the changes in propionate and acetate could be related to effects on the rumen protozoa, because polyunsaturated fatty acids are also toxic to rumen protozoa (Oldick and Firkins, 2000). The microbial defaunation by high-grain diets have similar effects on the fermentation pattern (Mendoza et al., 1993). The total concentration of volatile fatty acids must be carefully evaluated, because the process of absorption is a function of the $\mathrm{pH}$ and the concentration gradient. Fievez et al. (2003) reported no changes in total volatile fatty acid concentrations, but Toral et al. (2009) observed a reduction in the volatile fatty acid concentration. The ruminal ammonia $\mathrm{N}$ concentrations were not affected by the concentrations of fish oil used in this experiment, which is in contrast with other studies that reported increases in this metabolite in sheep (Toral et al., 2009) and cattle with $50 \mathrm{~g} / \mathrm{kg}$ fish oil in high-grain diets (Kook et al., 2002).

Leptin mRNA has been positively correlated with the adipocyte volume in steers (Yang et al., 2003) and blood leptin concentrations have shown positive relationships with body fat content in sheep across a broad range of ages and body weights (Altmann et al., 2005). Chilliard et al. (2001) found that leptin plasma concentrations were lower in a group fed a diet with a moderate energy content compared with a group fed a diet with high-energy content. However, in this study, the differences in energy intake did not change the expression of the leptin gene.

Decreases in feed intake in finishing ruminants have been associated with an increase in leptin, which is involved in the homeostatic regulation of body energy by regulating appetite (Ban-Tokuda et al., 2008). Higher concentrations of fish oil reduced intake and tended to show the highest leptin gene expression; although gene expression was not 
significantly affected, the logarithmic scale should be taken into consideration. Puglisi et al. (2011) concluded that the $n-3$ fatty acids present in fish oil could increase the expression of leptin in the adipocytes via PPAR gamma. The PPAR isotypes in ruminants are activated by longchain fatty acids (Bionaz et al., 2013).

Although fish oil is an expensive ingredient, its inclusion reduces the amount of grain and improves the efficiency of feed utilization, which results in increased partial net income per animal. The results were similar to those reported in Mexico for lamb feedlot rations with exogenous enzymes (Mendoza et al., 2105). Inclusion levels will depend on the cost, since future demand for fishmeal will be higher by sectors such as aquaculture, livestock feed, pharmaceutical production, and cosmetic production (FAO, 2012).

\section{Conclusions}

Lamb performance can be improved in finishing diets with the inclusion of $12.0 \mathrm{~g} / \mathrm{kg}$ fish oil dry matter. However, care must be taken when feeding fish oil to finishing lambs at higher concentrations because of the observed impairment of all performance variables. The concentrations of fish oil evaluated do not affect the expression of the leptin gene in the perirenal adipose tissue.

\section{Acknowledgments}

This project was supported by the annual internal funding from the Universidad Autónoma del Estado de México, Universidad Autónoma de Chapingo, and Universidad Autónoma Metropolitana.

\section{References}

Altmann, M.; Sauerwein, H. and Von Borell, E. 2005. Relationship between plasma leptin concentrations and carcass composition in fattening mutton: a comparison with ultrasound results. Journal of Animal Physiology and Animal Nutrition 89:326-330.

Annett, R. W.; Carson, A. F.; Fearon, A. M. and Kilpatrick, D. J. 2011. Effects of supplementation with fish oil and barium selenite on performance, carcass characteristics and muscle fatty acid composition of late season lamb finished on grass-based or concentrate-based diets. Animal 5:1923-1937.

AOAC - Association of Official Analytical Chemists. 2000. Official methods of analysis. 17th ed. Association of Official Analytical Chemists, v.1. AOAC, Arlington, VA.

Ban-Tokuda, T.; Delavaud, C.; Chilliard, Y. and Fujihara, T. 2008. Plasma leptin, feed intake and body fat accumulation in fattening castrated male and female lambs. Animal Science Journal 79:58-67.

Bionaz, M.; Chen, S.; Khan, M. J. and Loor, J. J. 2013. Functional role of PPARs in ruminants: potential targets for fine-tuning metabolism during growth and lactation. PPAR Research, Art ID 684159. http://dx.doi.org/10.1155/2013/684159

Bonnet, M.; Delavaud, C.; Bernard, L.; Rouel, J. and Chilliard, Y. 2009. Sunflower-seed oil, rapidly degradable starch, and adiposity up-regulate leptin gene expression in lactating goats. Domestic Animal Endocrinology 37:93-103.

Chikunya, S.; Demirel, G.; Enser, M.; Wood, J. D.; Wilkinson, R. G. and Sinclair, L. A. 2004. Biohydrogenation of dietary n3 PUFA and stability of ingested vitamin $\mathrm{E}$ in the rumen and their effects on microbial activity in sheep. British Journal of Nutrition 91:539-550.

Chilliard, Y.; Bonnet, M.; Delavaud, C.; Faulconnier, Y.; Leroux, C.; Djiane, J. and Bocquier, J. 2001. Leptin in ruminants. Gene expression in adipose tissue and mammary gland, and regulation of plasma concentration. Domestic Animal Endocrinology 21:271-295.

Chilliard, Y.; Delavaud, C. and Bonnet, M. 2005. Leptin expression in ruminants: Nutritional and physiological regulations in relation with energy metabolism. Domestic Animal Endocrinology 29:3-22.

Draper, N. R. and Smith, H. 1998. Applied regression analysis. 3rd ed. John Wiley and Sons Inc., New York, USA.

Erwin, E. S.; Marco, G. J. and Emery, E. 1961. Volatile fatty acids analysis of blood and rumen fluid by gas chromatography. Journal of Dairy Science 44:1768-1771.

FAO - Food and Agriculture Organization of the United Nations. 2012. The state of world fisheries and aquaculture. Opportunities and challenges. Food and Agriculture Organization of the United Nations, Rome.

Ferreira, E. M.; Pires, A. V.; Susin, I.; Gentil, R. S.; Parente, M. O. M.; Nolli, C. P. Meneghini, R. C. M.; Mendez, C. Q. and Ribeiro, C. V. D. M. 2014. Growth, feed intake, carcass characteristics, and meat fatty acid profile of lambs fed soybean oil partially replaced by fish oil blend. Animal Feed Science and Technology 187:9-18.

Fievez, V.; Dohme, F.; Danneels, M.; Raes, K. and Demeyer, D. 2003. Fish oils as potent rumen methane inhibitors and associated effects on rumen fermentation in vitro and in vivo. Animal Feed Science and Technology 104:41-58.

Havel, P. J. 2004. Update on adipocyte hormones: Regulation of 250 energy balance and carbohydrate/lipid metabolism. Diabetes $53: 143-151$

Ingvartsen, K. L. and Boisclair, Y. R. 2001. Leptin and the regulation of food intake, energy homeostasis and immunity with special focus on periparturient ruminants. Domestic Animal Endocrinology $21: 215-250$

Kitessa, S. M.; Gulati, S. K.; Ashes, J. R.; Flek, E.; Scott, T. W. and Nichols, P. D. 2001. Utilization of fish oil in ruminants I. Fish oil metabolism in sheep. Animal Feed Science and Technology 89:189-199.

Kook, K.; Choi, B. H.; Sun, S. S.; Garcia, F. and Myung, K. H. 2002. Effect of fish oil supplement on growth performance, ruminal metabolism and fatty acid composition of longissimus muscle in Korean cattle. Journal Animal Science 15:66-71.

Kumar, B.; Francis, S. M.; Suttie, J. M. and Thompson, M. P. 1998. Expression of obese mRNA in genetically lean and fat selection lines of sheep. Comparative Biochemistry and Physiology - Part B 120:543-548.

Marinova, P.; Popova, T.; Banskalieva, V.; Raicheva, E.; Ignatova, M. and Vasileva, V. 2007. Effect of fish oil supplemented diet on the performance, carcass composition and quality in lambs. Bulgarian Journal of Agricultural Science 13:729-737.

McCullough, H. 1967. The determination of ammonia in whole blood by direct colorimetric method. Clinica Chimica Acta 17:297-304.

Mendoza, M. G. D.; Britton, R. A. and Stock, R. A. 1993. Influence of ruminal protozoa on site and extent of starch digestion and ruminal fermentation. Journal Animal Science 71:1572-1578. 
Mendoza, G. D.; Aguilera, P. U.; Aguilera, P. M. I.; Pérez, S. M. A.; Hernández, G. P. A. and Espinosa, A. E. 2015. Economic evaluation of amylolytic enzymes in finishing lambs diet in Mexico. Life Science Journal 12:10-15.

NRC - National Research Council. 2007. Nutrient requirements of small ruminants. National Academy of Science, Washington, DC.

Oldick, B. S. and Firkins, J. L. 2000. Effects of degree of fat saturation on fiber digestion and microbial protein synthesis when diets are fed twelve times daily. Journal Animal Science 78:2412-2420.

Puglisi, M. J.; Hasty, A. H. and Sarasw, V. 2011. The role of adipose tissue in mediating the beneficial effects of dietary fish oil. Journal of Nutritional Biochemistry 22:101-108.

Russell, J. B.; Muck, R. E. and Weime, P. J. 2009. Quantitative analysis of cellulose degradation and growth of cellulolytic bacteria in the rumen. FEMS Microbiology Ecology 67:183-197.

Sadri, H.; Mielenz, M.; Morel, R.; Bruckmaier, M. and van Dorland, H. A. 2011. Plasma leptin and mRNA expression of lipogenesis and lipolysis-related factors in bovine adipose tissue around parturition. Journal of Animal Physiology and Animal Nutrition 95:790-797.

Sall, J.; Lehman, A.; Stephens, M. and Creighton, L. 2012. JMP® Start Statistics: A guide to statistics and data analysis. SAS Institute Inc. Cary, NC, USA.

Silva, S. R.; Gomes, M. J.; Dias-da-Silva, A.; Gil, L. F. and Azevedo, J. M. 2005. Estimation in vivo of the body and carcass chemical composition of growing lambs by real-time ultrasonography. Journal Animal Science 83:350-357.

Steel, G. D. R.; Torrie, J. H. and Dickey, D. A. 1997. Principles and procedures of statistics. A biometrical approach. 3rd ed. McGrawHill, New York, USA.

Tokuda, T.; Matsui, T.; Ito, J.; Torii, S. and Yano, H. 2000. The changes in body weight and plasma metabolite levels during leptin injection are caused by the reduction of food intake in sheep. Animal Science 70:343-348.

Toral, P. G.; Belenguer, A.; Frutos, P. and Hervas, G. 2009. Effect of the supplementation of a high-concentrate diet with sunflower and fish oils on ruminal fermentation in sheep. Small Ruminant Research 81:119-125.

Tricarico, C.; Pinzani, P.; Bianchi, S.; Paglierani, M.; Distante, V.; Pazzaglia, M. and Bustin, S. A. and Orlando, C. 2002. Quantitative real-time reverse transcription polymerase chain reaction: normalization to rRNA or single housekeeping genes is inappropriate for human tissue biopsies. Analytical Biochemistry 309:293-300.

Van Soest, P. J.; Robertson, J. B. and Lewis, B. A. 1991. Methods for dietary fiber, neutral detergent fiber, and nonstarch polysaccharides in relation to animal nutrition. Journal of Dairy Science 74:3583-3597.

Wachira, A. M.; Sinclair, L. A.; Wilkinson, R.G.; Enser, M.; Wood, J. D. and Fisher, A. V. 2002. Effect of dietary fat source and breed on the carcass composition, n-3 polyunsaturated fatty acid and conjugated linoleic acid content of sheep meat and adipose tissue. British Journal of Nutrition 88:697-709.

Yang, S. H.; Matsui, T.; Kawachi, H.; Yamada, T.; Nakanishi, N. and Yano, H. 2003. Fat depot specific differences in leptin mRNA expression and its relation to adipocyte size in steers. Animal Science Journal 74:17-21.

Yildiz, S.; Blache, D.; Celebi, F.; Kaya, I.; Saatci, M.; Cenesiz, M. and Guven, B. 2003. Effects of short term high carbohydrate or fat intakes on leptin, growth hormone and luteinizing hormone secretions in prepubertal fat-tailed Tuj lambs. Reproduction in Domestic Animals 38:182-186.

Zeisel, S. H. and da Costa, K. A. 2009. Choline: An essential nutrient for public health. Nutrition Reviews 67:615-623. 